Article

\title{
Social Innovation and Sustainable Rural Development: The Case of a Brazilian Agroecology Network
}

\author{
Oscar José Rover ${ }^{1}$, Bernardo Corrado de Gennaro ${ }^{2}$ and Luigi Roselli ${ }^{2, *}$ \\ 1 Department of Zootechny and Rural Development, Federal University of Santa Catarina, \\ Florianópolis-SC 88034-001, Brazil; oscar.rover@ufsc.br \\ 2 Department of Agricultural and Environmental Science, University of Bari Aldo Moro, 70126 Bari, Italy; \\ bernardocorrado.degennaro@uniba.it \\ * Correspondence: luigi.roselli@uniba.it; Tel.: +39-080-544-2883
}

Academic Editor: Sanzidur Rahman

Received: 28 September 2016; Accepted: 16 December 2016; Published: 22 December 2016

\begin{abstract}
Food is central to human beings and their social life. The growing industrialization of the food system has led to a greater availability of food, along with an increasing risk perception and awareness in consumers. At the same time, there is an increasing resistance from citizens to the dominant model of production and a growing demand for healthy food. As a consequence, an increasing number of social networks have been formed worldwide involving the collaboration between producers and consumers. One of these networks, the Ecovida Agroecology Network, which operates in Southern Brazil, involves farming families, non-governmental organizations, and consumer organizations, together with other social actors. Using a qualitative approach based on participant observation and an analysis of documents, the article examines this network. The theoretical framework used is social innovation, which is commonly recognized as being fundamental in fostering rural development. Results show that Ecovida has instigated innovations that relate to its horizontal and decentralized structure, its participatory certification of organic food, and its dynamic relationship with the markets based on local exchanges and reciprocal relations. Furthermore, such innovation processes have been proven to impact on public sector policies and on the increasing cooperation between the social actors from rural and urban areas.
\end{abstract}

Keywords: Ecovida Agroecology Network; social innovation; participant observation; Alternative Food Networks; Participatory Guarantee Systems (PGS); sustainable rural development

\section{Introduction}

Rural areas generally lack support in their development, as urban investment normally provides quicker and larger returns. Investment and innovation, however, are required in order to develop any rural or urban area. With limited private funding and public support, social innovation projects (defined in Section 2) are important for the development of rural areas. Social innovation is a key element for any institution, movement, or social network in terms of both organizational and territorial development. However, the development of rural areas also needs the support of public policies.

One way to innovate within rural areas is to transform the organization of the food system into a decentralized social network, acting over a wide geographical area, generating favourable conditions for small-scale farmers to improve their access to the market and to receive differential treatment from public policies (e.g., the institutionalization of participatory certification schemes, structural support to organize local and network markets). This is the working principle of Rede Ecovida de Agroecologia (Eco-life Network for Agroecology, hereinafter referred to as Ecovida), which operates in Southern Brazil and promotes many social innovation initiatives. 
This article focus on Ecovida and its dynamics, in order to highlight the role of social innovation in fostering rural development. It is organized as follows. Section 2 reviews the literature on social innovation and its relationship with sustainable rural development. Section 3 explores the Ecovida case study in depth and demonstrates how this network and its initiatives can be interpreted as social innovations. Finally, Section 4 discusses the results and presents the conclusions of the study.

\section{The Theoretical Framework: Social Innovation and Rural Development}

In his book "The Theory of Economic Development", written in 1912, Schumpeter [1] was the first academic to thoroughly investigate the relationship between development and innovation. His approach shows a clear economic bias and a focus on technology. He also highlights that there is often a cooperative element to an enterprise, which could be interpreted as social innovation, although he does not use this specific term. Following Schumpeter's lead, subsequent research on innovation focused on economic and technological issues within urban contexts. However, in the literature there is still little focus on rural areas and social innovation initiatives, apart from the significant contribution of a few authors [2-5].

Schumpeter's notion of innovation involves a break with the previous development of a given territory. Many of his followers, now called Neoschumpeterians, follow his premises, but interpret the innovations according to their own contexts and historical timelines. As they study innovations in terms of their technological elements, they introduced the notion of "technological trajectory" defined as "a process that generates technological changes over time, indicating how those innovations interact with each other and how they follow a given development pattern" [6] (p. 258). Institutional theories on development have a similar notion but without a technological specification, which they call "path-dependence", referring to "random and remote facts in time (which) have a clear influence on institutional evolution" [7] (p. 114). These approaches underline the importance of history in understanding social and innovative processes.

In the last few years, as the global preoccupation with environmental sustainability has grown, as also confirmed by the 2015 Paris Agreement on Global Warming [8], the interest in innovations that promote sustainable development have been increasingly valued, with greater emphasis on governance initiatives based on the involvement of communities. Neumeier [3] states that a lack of social innovation restrains vitality and the further development of rural areas. In his opinion, social innovation is the foundation of sustainable rural development. Bock [5] highlights the importance of the "global financial crisis, which produced massive public budget cuts" to stimulate the prominence of "self-determination, self-help and self-reliance as components of social innovation" [5] (pp. 555-556). She emphasizes "the problematic side of social innovation (...) as promoted like a solution in a context where the development base is also weakened as a result of policy interventions" [5] (p. 559).

In many cases, social innovation is perceived as an invention, as a change linked to the economy or technology, or as a result of organizational innovation. Social innovation, however, goes beyond these meanings. Neumeier [3] (p. 55) shows that social innovation happens when there is a change in attitudes, behaviour, or perception within a group who enters a network in which people work around common interests, setting up new paths to collaborative action within, or beyond, the borders of the group. According to this author, although innovation occurs within a specific social group, this improvement should be understood within the broader context of where the social innovation occurs.

From another viewpoint, Murray, Grice, and Mulgan [2] (p. 3) consider that social innovation means new products, services, and organization models which meet social needs, create new relationships and collaborations, and provide new possibilities for action for the society in which these changes occur. Additionally, Caroli et al. [4] interpret social innovation as processes that transcend the social, itself, regarding the production of goods and services as a way of overcoming social and environmental problems, as well as market failures. Bock [5] (p. 561), together with the previous authors, place social needs at the core of social innovation. On the other hand, Neumeier [3] suggests that, although needs are important for social innovation, it is also possible to interpret social 
innovation beyond the focus on needs. According to Aléssio and Rover [9] (p. 116), social innovation depends on "organizational dynamics (which) may form differently, according to local contexts in each territory, allied to technological processes adjusted to local routes, more or less dependent of each territory's history".

Neumeier [3] suggests that social innovations happen as social practices and not as technical artefacts, which depend on group work connected to social networks and the availability of social capital $[10,11]$. Such social practices need to be stimulated in order to lead to innovation, by both the internal and external agents of the initiatives. In this way social innovations develop in terms of collaborative action, representing novelty in the subjective perception of the individuals involved and in their attitudes and behaviour. Their practical implementation is connected to a vision of superiority as a solution to existing methods, with its main focus on the construction of social skills and assets, and not on the fulfilment of social needs. Thus, according to Neumeier, the material results are merely additional, as the focus of social innovations is not materialistic.

Murray, Grice, and Mulgan [2] highlight six stages of social innovation, which they see as non-mandatory, as well as non-linear: (1) inspiration and social context; (2) proposals and ideas; (3) building prototypes and experiments; (4) confirming the innovation; (5) organizing and promoting the growth and expansion of the experiment; and (6) changes in the reference system which, as an ultimate goal of social change, involves structural changes within the context where the innovation occurs. Conversely, Neumeier [3] presents a more academic proposal, focused on identifying the presence and organization of social innovation in different rural areas. His conceptual starting point is that social innovation represents the behaviour and perception changes within a group. Consequently, Neumeier limits his study to the strict social character of innovation. He believes that there are three key stages of social innovation: (a) problematization, which is triggered by an initial impulse that stimulates social actors to act; (b) drawing attention, engaging, and increasing the interest in innovation of the social group/s involved; and (c) coordinating participants in implementing new behaviours, during which a dynamic co-learning process develops.

To date, empirical studies on social innovation are still limited, both in urban and rural areas. Since social innovation in rural contexts is much more important for the promotion of development, due to their higher socioeconomic vulnerability, the main object of this study is to analyse the specific processes of social innovation promoted by Ecovida in the rural areas of Southern Brazil aimed at promoting a sustainable rural development. Based on the theoretical approach proposed by Neumeier [3] and Aléssio and Rover [9], we analyse the driving forces behind the participation of the social actors; the dynamics of the actor-network underlying its composition and organizational changes: the importance of non-social elements in the decisions taken by social actors. We also investigate the dependence and relationship of the general organizational dynamics of Ecovida in each micro-region, as well as Ecovida's relationship with sector policies.

\section{The Case of Rede Ecovida de Agroecologia}

\subsection{Methodological Approach}

The method chosen to examine the role of social innovation in fostering rural development is the case study approach. This qualitative method studies the characteristics of a particular entity or phenomenon, and is helpful for exploring a complex research area about which little is known. The case study we focused on is the Rede Ecovida de Agroecologia (Ecovida). The research is based on combined data collection tools: participant observation and an analysis of documents. Participant observation has occurred throughout the network's existence, through the direct participation of one of the authors at Ecovida from its foundation. The analysis of documents focused on Ecovida's official documents and scientific papers [12-24] in order to describe the features and the dynamics of the organization. 
In this section, the qualitative data gathered are synthesized and interpreted to describe the Ecovida experience, from its foundation up to the present, using the theoretical scheme proposed by Neumeier [3] and Aléssio and Rover [9].

\subsection{History, Organization and Social Innovation}

Ecovida was created in November 1998 in the state of Santa Catarina. The initial external problematization was caused by the state government of Santa Catarina which had, earlier in the year, launched a program for the regulation and certification of organic products in the state. In order to resist this initiative, a group of non-governmental organizations (NGOs) joined together to build a non-state alternative to this policy. In 1999, Ecovida had already reached out to the entire southern region of Brazil (Figure 1), a region in which the NGO network, known as the Rede Tecnologias Alternativas (Alternative Technology Network), was already operative. In this year, the first meeting of farmer groups (FGs), NGOs, and other interested organizations took place, having changed the network's name to "Rede Ecovida de Agroecologia".

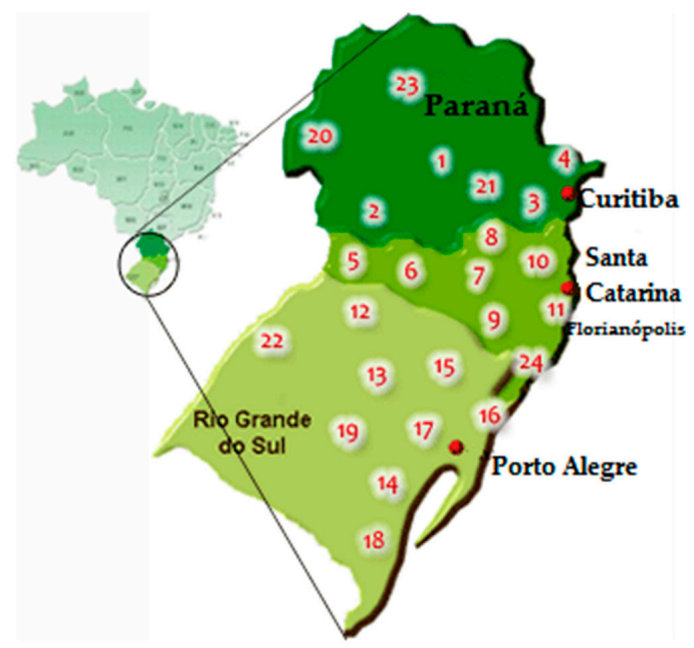

Figure 1. Map of Brazil with the geographical reach of Rede Ecovida and its regional centres. Source: [14].

The establishment of Ecovida highlights some important issues regarding the process of social innovation. Its original mission, which was clearly external and governmental, led some organizations to join in opposition to a centralized certification model which did not respect the history of the pioneer farmers and organizations who were already adopting organic methods in the area. Since its foundation, this network has been promoting a participatory certification scheme with its own label integrating the social actors involved in the network. More than a certification label for the products, the process involved agro-ecological production, joint working, and mutual social learning.

Ecovida's social innovation has always focused on benefitting agroecological family farmers and their organizations. Groups of family farmers have been set up, particularly in regions with supporting NGOs (or through joint efforts when such groups already existed). These groups are the organizational core of Ecovida. To become part of the network, farmers need to belong to a farmer group (FG) and each group is linked to a regional centre (RC), which acts as the main functional body of its organizational dynamics.

Figure 1 shows the location of the RCs in 2015, which had extended to a large area seventeen years after its foundation. Table 1 presents the historic evolution of the number of members and organizations connected to Ecovida. It started with 343 farming families, 35 farmer groups, and four NGOs in 1999, and by 2016 there were 4500 farming families, 300 farmer groups, 30 NGOs, and 28 RCs. Its growth is tied to the social capital it built up and to the increasing demand for organic food both 
in Brazil and internationally [25]. The growth in consumer organizations connected to Ecovida is in line with the growth in demand, which proves the potential of this network to involve organizations beyond the rural areas.

Table 1. Evolution of the Ecovida network.

\begin{tabular}{ccccccccc}
\hline Year & $\begin{array}{c}\text { Farmer } \\
\text { Families }\end{array}$ & $\begin{array}{c}\text { Farmer } \\
\text { Groups }\end{array}$ & Municipalities & NGOs & $\begin{array}{c}\text { Consumer } \\
\text { Organizations }\end{array}$ & $\begin{array}{c}\text { Regional } \\
\text { Centres }\end{array}$ & Traders & Agro-Industries \\
\hline 1999 & 343 & 35 & N/A & 4 & N/A & N/A & N/A & N/A \\
2005 & 2438 & 272 & 180 & 28 & 06 & 21 & N/A & N/A \\
2007 & 2700 & 290 & 205 & 35 & 08 & 24 & N/A & N/A \\
$2009^{*}$ & 3000 & 300 & 220 & 35 & 08 & 25 & N/A & N/A \\
$2011^{* *}$ & 2444 & 213 & 178 & 35 & 21 & 17 & 39 & 113 \\
2016 & 4500 & 300 & 170 & 30 & 20 & 28 & N/A & N/A \\
\hline
\end{tabular}

Produced by the authors. Sources: [20-22]. NGOs: non-governmental organizations. ${ }^{*}$ For 2009 it is difficult to assess the precise data from the whole of Rede Ecovida [15-21]; ** According to the author [22] only 17 Regional Centres answered his survey, despite 24 confirming their existence. This means that there was no decrease in the Ecovida numbers for this specific year.

Ecovida is a horizontal and decentralized network, and takes non-binding decisions, which are accepted by the majority of its members but which, in some cases, are not fully integrated at a local level. Different levels of progress depend on the capacity of each RC's organization. In some regions, Ecovida has strong organizational connections, which are not so developed in others. The fragility of several RCs is demonstrated by the lack of information provided by Ecovida, by not knowing exactly how many family farmers and organizations are associated with it.

By opposing the hegemonic and centralized development model, many endeavours have focused on the micro, specific, and immediate, despite the fact that many organizations have a strategic vision for how this model could be transformed [26]. Starting with the construction of local alternatives to the hegemonic paradigm, networks, such as Ecovida, came together to coordinate a number of organizations with common social transformation projects. Due to the micro-regional and/or sectorial activities of many social organizations, networking was regarded as a solution to increase their effectiveness. Especially from the 1990s onwards, as they brought alternative and significant experiences together, many local organizations formed social networks, such as Ecovida, in order to promote a common action. Many networks with similar profiles have been set up in Southern Brazil, such as NGOs, solidarity economies, family agro-industries, popular enterprises, or credit structures [13]. These could be considered as part of the so-called Alternative Food Networks (AFNs) [27,28]. In fact, according to Renting et al. [27], AFN is "a broad embracing term to cover newly emerging networks of producers, consumers, and other actors that embody alternatives to the more standardised industrial mode of food supply".

Ecovida requires a member to participate in an organization (farmers' group, association, cooperative, etc.) in order to take part in its network. A farmer can participate in the Ecovida network only after joining a FG. This is a key condition for obtaining the organic certification of his/her produce. It is a decentralized network whose managerial decisions are taken at each RC, of which the FGs constitute the core engine. Despite its national coordination bodies, the network's decision-making is multi-directional as its role is secondary compared to FGs and RCs. These latter organs make decisions and select the organizational paths to follow.

The current organization of Rede Ecovida, as shown in Table 2, is the result of a historic path of each territory involved and their local organizational dynamics. Until the 1980s, the members of Rede TA-Sul carried out intense political and organizational training with family farmers from their own micro-regions. From the 1990s onwards, many of the NGOs of Rede TA-Sul directed their work more towards the productive sector through a method which would later be known as agroecology. This was an alternative to an agriculture, which depended on industrial inputs, on the market, and was based on the premises of the Green Revolution (it refers to the process of modernization of agriculture, 
started in the 1960s. It consists in the development of modern or high-yield crop varieties, particularly of corn, rice and wheat, released to farmers in Latin America and Asia, associated with the intense use of capital, improved seeds, chemical inputs, and moto-mechanization). As productive practices advanced, it was also necessary to establish trading locations which enabled producers to make a profit from agroecological production. Pedagogically speaking, it is possible to assign four stages to the organizational dynamics of the territories of Ecovida up to the present (Table 3).

Table 2. Decision and organizational bodies of Ecovida.

\begin{tabular}{ll}
\hline Organizational Bodies & Decision and Organization \\
\hline Plenary Meeting & $\begin{array}{l}\text { Every two years with all those who are part of the Network. It works as a General } \\
\text { Assembly where strategic guidelines are decided. }\end{array}$ \\
\hline General Assembly of RCs & With two members of each regional centre (RC) with two meetings per year. \\
\hline Coordination Meetings & $\begin{array}{l}\text { Where decisions from the Plenary Meetings and General Assembly of RC's are } \\
\text { put into action, working at two levels: (a) General Coordination; (b) Coordination } \\
\text { in each State (Paraná, Santa Catarina and Rio Grande do Sul). }\end{array}$ \\
\hline Regional Centres & $\begin{array}{l}\text { Spread across micro-regions in southern Brazil, these assume specific } \\
\text { organizational strategies with respect to their own specific situations, led by the } \\
\text { principles and guidelines of Ecovida. They are made up of: (i) Coordination; } \\
\text { (ii) Secretariat; (iii) Financial Sector; (iv) Ethics Committees *; (v) Groups. }\end{array}$ \\
\hline
\end{tabular}

Source: Based on Perez-Cassarino [22] and Ecovida [14]. * Ethics committees guarantee the application of principles and rules of Ecovida by all of its members. They exist in the groups, RCs, and throughout the network.

Table 3. Historical steps in the organization dynamics of family farmers in the Ecovida territories.

\begin{tabular}{cll}
\hline Year & \multicolumn{2}{c}{ Stage } \\
\hline 1970s/1980s & $\begin{array}{l}\text { Stage 1: Political organization of family farmers and } \\
\text { setting-up of social and political organizations }\end{array}$ & \\
\hline 1990s & $\begin{array}{l}\text { Stage 2: Food production based on alternative farming } \\
\text { (agroecology), adding value to local agro-biodiversity }\end{array}$ & $\begin{array}{l}\text { Transition from the 1990s to the 2000s matches the } \\
\text { creation of Ecovida, characterized by a global } \\
\text { increase in organic street markets and the need to } \\
\text { offer trade opportunities to develop agroecological } \\
\text { production with the establishment of trading posts }\end{array}$ \\
\hline \multirow{2}{*}{$2000 \mathrm{~s}$} & $\begin{array}{l}\text { Stage 3: Trading produce as well as fostering a national } \\
\text { proposal for participatory certification of } \\
\text { organic productions }\end{array}$ & $\begin{array}{l}\text { Stage 4: Strengthening of elements from previous stages, } \\
\text { adding more focus on trade and production and less on } \\
\text { valuing political and organizational training }\end{array}$ \\
\hline \multicolumn{2}{c}{ Source: Stages 1 and 2 adapted from Arns et al. [13] and Arl [12]. }
\end{tabular}

In the 1990s, the spread of street markets for organic produce required norms that guaranteed their quality, also requiring Ecovida-related groups to be involved in the market development of their practices. In 1998 these organizations, with clear pro-social ideals, then created Rede Ecovida de Certificação Participativa (Ecovida Network for Participatory Certification) in order to guarantee the organic quality of their products. As they understood that this process would limit their approach to such a specific element such as certification, they changed their designation to Rede Ecovida de Agroecologia (Eco-life Network for Agroecology). This change is a social innovation itself. In fact, the network brings together two new elements: the Participatory Guarantee System (PGS) and its social setup of the market.

\subsection{Functioning of Participatory Guarantee Systems (PGS)}

It is not possible to distinguish the higher quality of organic products just by their aesthetic appearance compared with products from conventional agriculture where chemically-synthesized products (e.g., pesticides, fertilizers) are used. This makes the organic quality cue a credence attribute for which the market success relies on the trust between producers and consumers. Brazil thus created three forms of guarantee systems for organic quality assurance [29]:

(1) Third-party certification, operated by an independent company, subject to Conformity Assessment Bodies (in Portuguese: Organismos de Avaliação da Conformidade, or OAC); 
(2) Participatory Guarantee Systems, operated by a Participatory Body for Conformity Assessment (in Portuguese: Organismos Participativos de Avaliação da Conformidade, or OPAC), under which Ecovida operates; and

(3) Social Control Organizations (in Portuguese: Organização de Controle Social, or OCS), operated by local organizations, intended to be used only to sell products according to direct marketing strategies.

Each of these accredited guarantee systems enable the trade of produce across different regions. However, third-party certification permits the use of the label of the Brazilian System for the Evaluation of Organic Compliance, thus enabling the international sale of the produce because it conforms to international rules. Participatory Guarantee Systems also allow the use of such labels, but the sales are limited to within Brazil. As for the accreditation by a Social Control Organization, this can only be used by family farmers and only permits them to sell directly at local consumption points.

Now let us turn to the work Ecovida carries out with participatory certifications. Ecovida has played a key role in the formulation of this kind of guarantee system under Brazilian law. In order to promote participated certification, as a social innovation, recognition by law was required. Due to its experience, Ecovida worked together with the federal government and played a central role in the shaping of this certification scheme. Social innovation, in Ecovida, does not represent the state's withdrawal, as there is still a link between the state and civic organizations. In this case there is no "at distance of state support" [5] (p. 569), but cooperation to establish the norms and operate the participatory certification.

Participatory certification involves the exchange of knowledge and shared learning between its members, as well as a specific inspection by crossed monitoring. To perform this control, farmers within the same network or organization, but from different groups, visit and monitor other producers, with special focus on any cases of non-compliance. Non-compliance of rules is very important because it harms the whole organization, affecting the Ecovida label itself. This method of cross-monitoring can be particularly effective for organic production and trade, as it stimulates the exchange of knowledge, seeds, and other elements that make up its organizational capital. As for Ecovida, Frison, and Rover [17] show how expertise and experiences are exchanged within each group and among different groups: in terms of handling techniques, control methods, as well as the general knowledge of organic production. There is also a broader awareness of the Brazilian legislative bodies regarding the efficiency of this certification method.

The success of the two systems for organic quality assurance that do not require a third-party involvement (OPAC and OCS) is supported by the wide adhesion of Brazilian farmers (Figure 2).

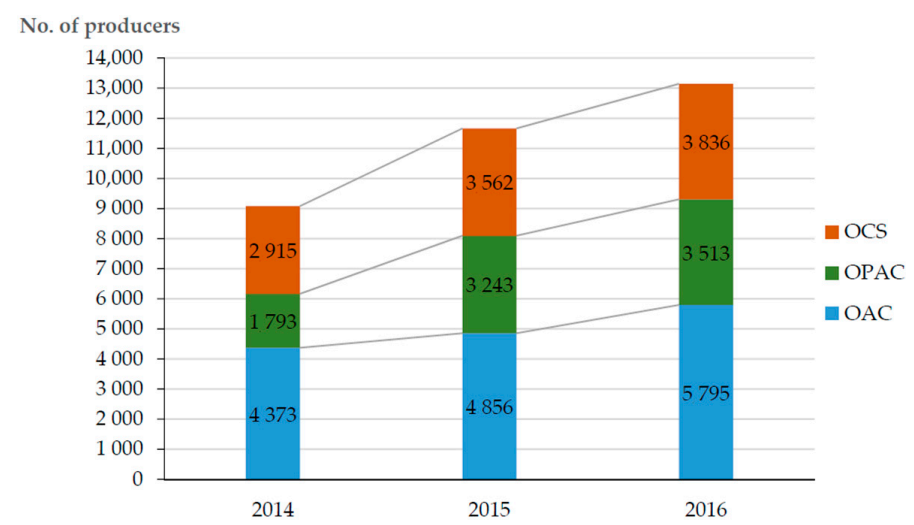

Figure 2. Number of organic producers in Brazil according to the organic accreditation system. OAC: Third-party certification; OPAC: Participatory Guarantee Systems; OCS: Social Control Organizations. Source: Brazilian National Register of Organic Producers [30]. 
In 2006, 90,497 farms across Brazil declared that they were producing agroecologically, but only 5106 were certified as organic [31]. Ten years later, in 2016, the organic certification system included 13,144 registered farms [23], most of which are certified under OPAC and OCS systems. From 2006-2016, the number of certified producers grew by 144\%. In the last three years, from 2014 to 2016 , the total growth rate was almost $45 \%$, but the highest increase was recorded for producers involved in the OPAC scheme (+96\%) (Figure 2). The high costs and bureaucracy involved in the process of accreditation explain the difference in the numbers between the self-declared organic producers and those actually certified. Additionally, the lower accreditation costs and bureaucracy explain the success of the OPAC and OCS accreditation systems. Ecovida represents nearly $70 \%$ of Brazilian producers certified by OPAC, although its geographical operations are limited to Southern Brazil, where it represents nearly $100 \%$ of the participatory certification farmers.

Ecovida certification is first produced within each FG as the network's relationship is with the group and not with each individual farmer. In this way the group is certified and not the producers themselves, although legislation requires each producer's product to be labelled. The main inspection within this certification model is then carried out by a neighbouring producer who does not want any misconduct from his/her fellow producers to negatively impact on his/her own production or label. In addition to the inspection of producers, RCs include an ethics committee, whose members take the responsibility for documenting and coordinating the certification procedures. Another task of the RC is the promotion of knowledge exchange between farmers from different groups.

Although there are significant positive elements, the Ecovida participatory certification has two important weaknesses: (i) its potential markets are restricted because this kind of certification only permits commercialization in Brazil; and (ii) there is a risk that one "free rider" member of the network may perform an illegal action, thus creating a problem for the Ecovida label.

Participatory Guarantee Systems, such as that promoted by Ecovida, can be regarded as a form of social innovation as they promote a change in attitudes, behaviour, and perceptions among its participants. They, thus, create new consolidated paths of collective action as well as representing a new model for the certification process of organic produce, in collaboration with the Federal Government of Brazil.

\subsection{Social Set-Up of the Markets}

Ecovida plays an active part in the Brazilian social movement of Solidarity Economy, aimed at "making farmers and consumers come closer" [16]. Its concept of agroecology originally gave priority to biodiverse production systems, and resists trading with wholesale or retail outlets. Trading has, in fact, become a barrier to the expansion of production and the management of Ecovida's producers, as the production grew in all RCs and the markets' capacity to absorb their produce was restricted [23]. This limitation has led organizations to set up new trade routes under a philosophy of fair trade, for example the Southern Circuit of Food Circulation. This then increased the number of local farmers' markets in some regions as well as providing a trading post (a Box) to gather and distribute food from the rural areas and organizations in a metropolitan area (Florianópolis). Of the many initiatives that exist, we will now briefly describe the three most important ones: the Trade Circuit; local and regional markets; and so-called Organic Trading Boxes. In describing these initiatives, we provide a general idea of the key elements that make them social innovations from a commercial perspective.

The Trade Circuit started in 2006 and is based in some RCs which act as meeting and distribution points for the traded products. These wholesale points, which sometimes operate retailing activities, also complement the supply of organic produce in each region with those from other RCs.

Figure 3 shows the evolution of the Trade Circuit between 2008 and 2016. It shows the expansion of the Circuit to other regions, and the greater integration and creation of new routes within different regions. This Circuit follows a set of principles that give it a distinctive character from other commercial systems. According to Magnanti [19], among these principles, the following need highlighting: (a) production must necessarily be from family farm agriculture, produced in diverse systems that 
guarantee the self-supply of the producing family; (b) selling organizations must also acquire products, as their primary goal is not monetary exchange, but to guarantee the diversity of available goods in each region; (c) the criteria for the establishment of a price list must be assessed regularly in order to guarantee that the work of farmer families is fairly paid and that products are accessible to consumers.

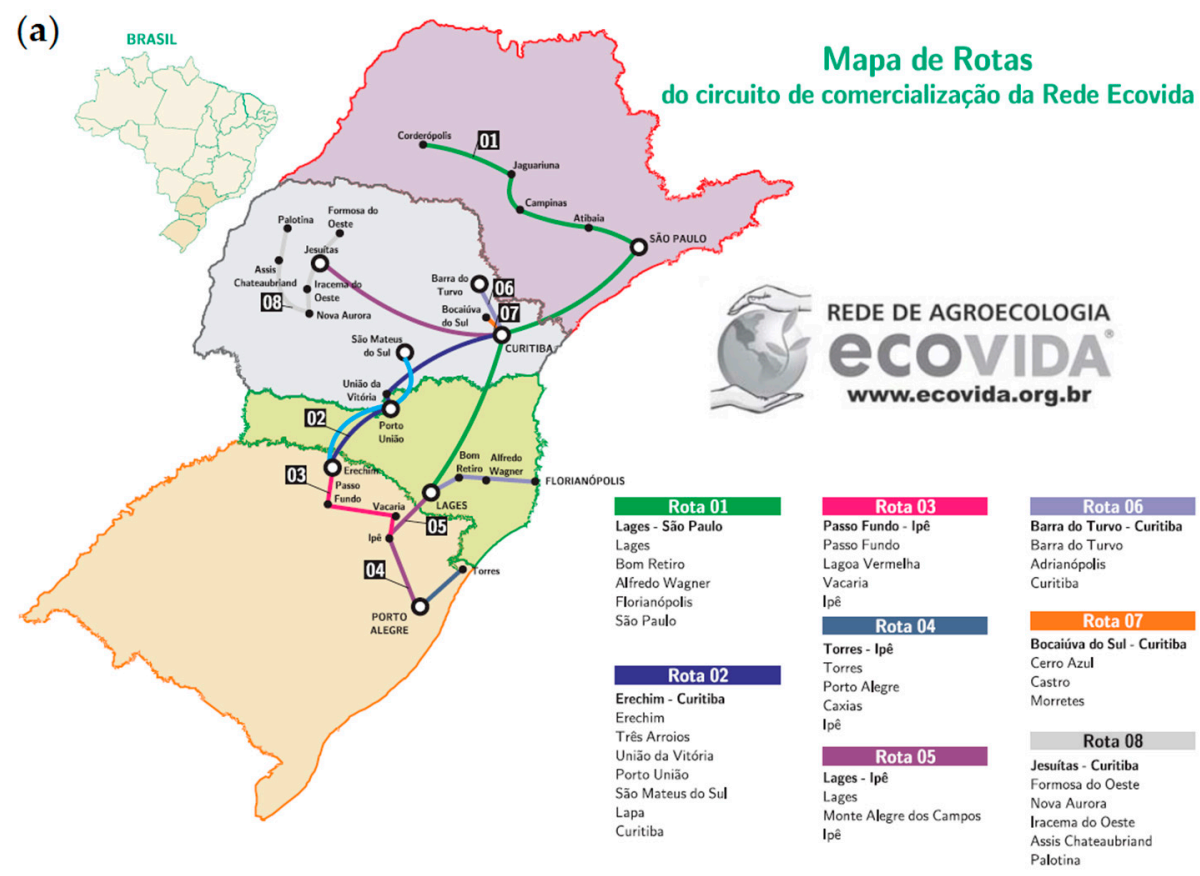

(b) Circuito de Circulação e Comercialização

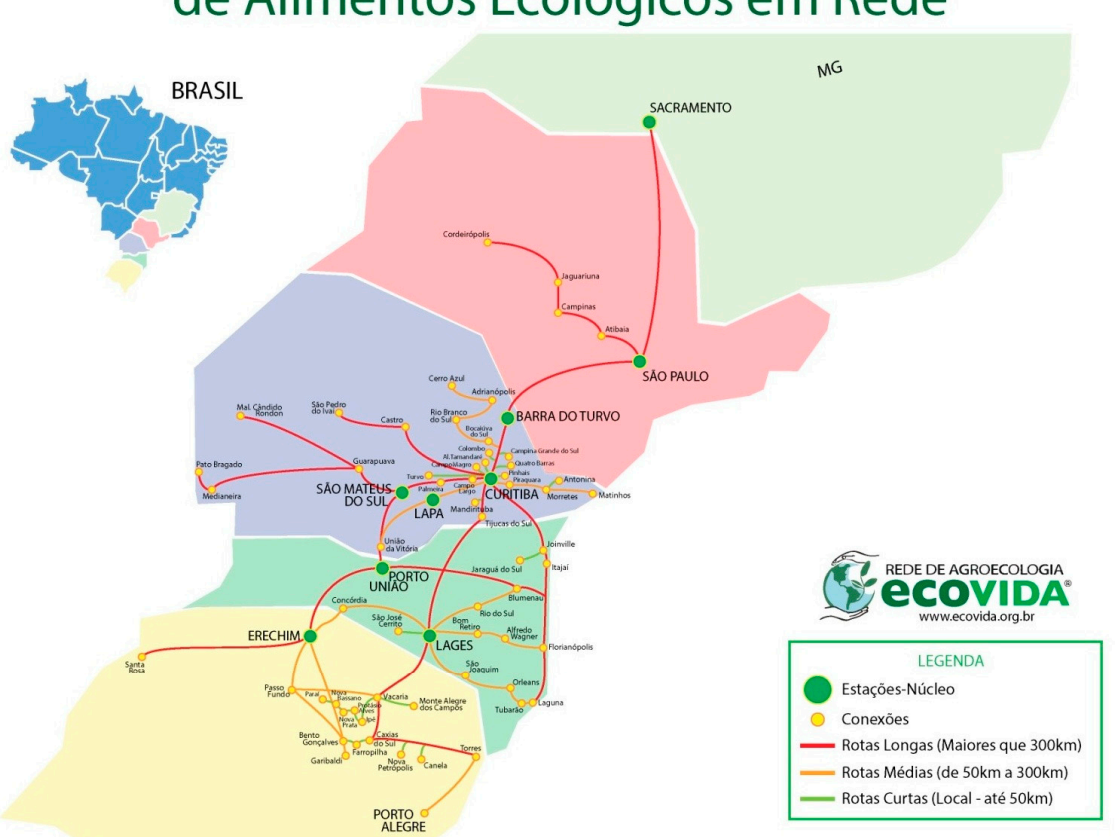

Figure 3. Route map of Ecovida Network's Trade Circuit in 2008 (a) and 2016 (b). Source: [15-19]. 
Local and regional markets are the primary and most important commercial strategy of Ecovida. "There are more than 100 free fairs for ecological produce and other means of trade in the entire territory of action of Ecovida" [14]. Its vision of agroecology aims to generate productive processes that sustain ecosystems and organizational dynamics, which guarantee the social reproduction of family farmers. Markets are socially equipped to fit this approach quite well. Despite being small-scale sale points, they are active and demonstrate the strategy of bringing producers and consumers together through direct trade and small commercial circuits. Together with these fairs, sales to institutions (such as local authorities for school meals, community centres) represent a commercial form that allows direct trade, enabling the RCs and their organizations to trade most of the farmers' produce in all its diversity.

The Box Orgânicos Florianópolis (Florianópolis Organic Trading Box), located in the Santa Catarina state capital and surrounded by its metropolitan area, is another commercial outpost that serves the innovative dynamics of Ecovida. It started out in 2013 but already supported the Trade Circuit, as well as the street markets. RC farmers and organizations from the area of this Box, as well as from other Ecovida centres, bring products from their regions, thus supporting each other and diversifying their food supply. Such networking, its mutual self-supporting nature, and the larger and wider-reaching supply network, as well as the diffusion of their influence, through cooperation, are gains that stand out from this experience.

The three briefly described examples of marketing initiatives show an innovation process that combines social and environmental goals with the economic mechanism of supply and demand, in order to produce scale returns and strengthen commercial logistics. The social and environmental ethics of Ecovida interact with commercial demands and create social innovation targeted at the economic viability of the family farmers associated with it. The "socially-built character of the economic regulations" [32] (p. 217), by which Ecovida is ruled, balances trading processes and endogenous market strategies.

In these commercial innovations of Ecovida, the different levels of state intervention have been important. For instance, many wholesale points were organized with the support of the Federal Government. Ecovida's commercial practices are also aimed at developing collaborative action within the network itself, generating new products, services and action models which enable these potential social innovations to be replicated. In order to join the network, the organizational dynamics of Ecovida oblige its agents to adapt to its rules. In some cases, ex-members acquire experience in the market and decide to pursue a "solo career". However, this may be also a positive element of its role as a laboratory to learn about the production, certification, and commercialization of organic products.

However, the dynamics proposed by Ecovida are facing various challenges, namely how to maintain its organizational principles while experiencing growth, whether in terms of territorial coverage or number of network members. From this perspective, it is also vital to activate additional ways to access the market in order to cope with the growing supply. The broadening of commercial practices should fulfil Ecovida's founding principles while promoting farmers' groups, which are one of the key elements in this network.

\section{Discussion and Concluding Remarks}

When working in networks such as Ecovida, the construction of new social projects requires the negotiation of interests and setting up common principles for collective guidelines. This results from a historical process connected to rural grassroots movements who opposed the hegemonic development model by proposing principles such as decentralization, social inclusion, or respect for local ecosystems. This process follows the vision shared by many alternative farming networks based on the philosophy of food democracy $[18,33,34]$.

Ecovida is an organizational network that innovates and transforms the agricultural systems in which it takes part. It has become the main production and organic certification network in Brazil. The need to open up markets to farmers and organizations has stimulated important trading 
innovations, such as those described above. The network resists conventional production methods with its top-down or directive organizational systems and trade mechanisms which set producers and consumers apart, while decisions regarding human food production, processing, and distribution have become increasingly centralized. Ecovida uses socially available tools, empowers and promotes new institutional structures, and broadens the opportunities for systemic transformation through diversified processes. The social innovation dynamic of Ecovida is also highlighted by its specific history resulting from production and organizational strategies and from the relationship with its own territorial context (Table 4).

Table 4. Main components in the social innovation and collaborative dynamics of Ecovida.

\begin{tabular}{|c|c|}
\hline $\begin{array}{l}\text { Analytical Elements of Social } \\
\text { Innovation }\end{array}$ & Characteristics of Ecovida \\
\hline $\begin{array}{l}\text { 1. Motivations for the participation } \\
\text { of its actors }\end{array}$ & $\begin{array}{l}\text { Ideological engagement by transforming the model of rural development, based } \\
\text { on agroecology and biodiversity. } \\
\text { Exchange of knowledge, seeds, information on methods and techniques, among } \\
\text { other things. }\end{array}$ \\
\hline $\begin{array}{l}\text { 2. Composition and dynamics of } \\
\text { actor-network }\end{array}$ & $\begin{array}{l}\text { A decentralized and multi-directional network where decision processes occur } \\
\text { simultaneously at different levels. } \\
\text { Open and transparent communication through a mailing list without any } \\
\text { management filters. }\end{array}$ \\
\hline $\begin{array}{l}\text { 3. Influence of non-social elements } \\
\text { on decisions of social actors }\end{array}$ & $\begin{array}{l}\text { Agrobiodiversity of production systems is prioritized. } \\
\text { The need for agrobiodiverse trade stimulates the organization and engagement in } \\
\text { specific markets. }\end{array}$ \\
\hline $\begin{array}{l}\text { 4. Dependence and relationship } \\
\text { with specific territorial processes } \\
\text { and general policies }\end{array}$ & $\begin{array}{l}\text { It influences public regulations and adapts itself to the norms of participatory } \\
\text { certification of organic produce. It has been supported by infrastructure to } \\
\text { improve its market dynamics, mainly by the Federal Government. } \\
\text { It has its own regulations with general principles and guidelines, following the } \\
\text { norms of national organic produce legislation. } \\
\text { RCs base their actions on the general principles and rules of the network but keep } \\
\text { a strong autonomy, working as the central functional organs of Ecovida. }\end{array}$ \\
\hline
\end{tabular}

Produced by the authors, based on the theoretical approach proposed by Neumeier [3] and Aléssio and Rover [9].

Just as social innovation is considered as a strategic pillar of development in rural areas, the diversification of ecosystems has been highlighted as the central constituent in redesigning sustainable agro-ecosystems [35]. When combined, diversification (through agroecology) and social innovation are two factors that have helped in the creation and growth of Rede Ecovida.

Ecovida represents a collective alliance to contribute to the growth of agroecology as a means of production and as a model of sustainable rural development. Belonging to Ecovida is, on the one hand, a territorial issue, as the network has deep roots in the effective and spatial dynamics of society. In addition, it also has an ideological aspect, for it is not only interested in produce, but also proposes new means of production and new rural development patterns. Arl [12] regards Ecovida as part of a social project which, at the same time, takes the reality of each ecosystem and territory into consideration.

Food trade, as with any other trade, has its own exchange circuit with tensions between socially-regulated paths, as well as diversions motivated by competition [36]. Ecovida, therefore, promotes diversions which correspond to a socio-economic strategy beyond market competition, in social conflict with conventional production, innovating towards an agro-food democracy. Quoting Appadurai [36] (p. 45), "diversions only have a meaning if associated with the paths from which deviation took place". In the conflict with and in opposition to conventional production, Ecovida has innovated by creating its own means of participatory certification and trade. It has, thus, innovated by promoting a deviation from the conventional methods of production, certification, and trade, creating alternatives that can be applied to other socio-productive contexts. It does this in conjunction with other social actors, of which the Federal Government of Brazil has been key in the last two decades. 
Altieri and Nicholls [35] highlight that for organic agriculture to be ecologically and socially sustainable, a social organization is required that is embedded with the values of ecology and sustainability. The choice of direct and local sales as the primary mechanism of distribution, followed by the exchange of products between RCs, through their Trade Circuit, strengthens both the territorial and organizational bonds within Ecovida, as well as between this organization and its partners. Its mechanisms of distribution enable farmers to grow a wider variety of produce. This gives them the opportunity for a less specialized production with less dependence on larger production scales. This can then facilitate a wider diversity in production and a better ecosystem, which is key to the ecological resilience of these agro-ecosystems.

The public spirit characterizing Ecovida creates new opportunities to produce and distribute organic food. In addition, organic production generates environmental services and public goods (e.g., biodiversity conservation, climate change mitigation, maintaining soil functionality, agricultural and rural landscape, rural vitality) [37]. Therefore, building actions and policies to favour the production, distribution, and consumption of organic food is of major importance, particularly when promoted by the citizens themselves. Ecovida provides essential social innovation which helps in the planning of other social and political initiatives, as well as public policies towards a truly sustainable agriculture and a better food democracy.

Acknowledgments: The authors would like to thank the two anonymous reviewers for their useful comments, needless to say that any shortcomings are the responsibilities of the authors alone. In addition, we are grateful to the Coordination for the Improvement of Higher Education Personnel (CAPES)-Brazil.

Author Contributions: Oscar José Rover, Bernardo Corrado De Gennaro and Luigi Roselli conceived, designed and performed the research; Oscar José Rover, Bernardo Corrado De Gennaro and Luigi Roselli analysed the data and wrote the paper.

Conflicts of Interest: The authors declare no conflict of interest.

\section{References}

1. Schumpeter, J.A. The Theory of Economic Development: An Inquiry into Profits, Capital, Credit, Interest and the Business Cycle; Opie, R., Ed.; Transaction Publishers: Piscataway, NJ, USA; London, UK, 2008.

2. Murray, R.; Caulier, J.; Mulgan, G.G. Il Libro Bianco Sulla Innovazione Sociale. Available online: http://www.societing.org/wp-content/uploads/Open-Book.pdf (accessed on 9 September 2016).

3. Neumeier, S. Why do social innovations in rural development matter and should they be considered more seriously in rural development research?-Proposal for a stronger focus on social innovations in rural development research. Sociol. Rural. 2012, 52, 48-69. [CrossRef]

4. Caroli, M.G. Modelli ed Esperienze di Innovazione Sociale in Italia: Secondo Rapporto Sull'Innovazione Sociale; International Center for Research on Social Innovation (CERIIS): Milano, Italia, 2015. (In Italian)

5. Bock, B.B. Rural marginalisation and the role of social innovation; A turn towards nexogenous development and rural reconnection. Sociol. Rural. 2016. [CrossRef]

6. Furtado, A. Opções tecnológicas e desenvolvimento do terceiro mundo. In Desenvolvimento e Natureza: Estudos para Uma Sociedade Sustentável, 3rd ed.; Cavalcanti, C., Ed.; Cortez/Fundação Joaquim Nabuco: São Paulo, Brazil, 2001; pp. 256-275.

7. Arend, M.; Cario, S.A.F.; Enderle, R. Instituições, inovações e desenvolvimento econômico. In Pesquisa $\mathcal{E}$ Debate. Revista do Programa de Estudos Pós-Graduados em Economia Política; Departamento de Economia da Pontifícia Universidade Católica de São Paulo: São Paulo, Brasil, 2012; Volume 23, pp. 110-133.

8. United Nations. Framework Convention of Climate Change. Paris Agreement. Available online: http:/ / unfccc.int/resource/docs/2015/cop21/eng/109r01.pdf (accessed on 9 September 2016).

9. Aléssio, B.C.; Rover, O.J. O desenvolvimento regional como processo de encadeamento de dinâmicas organizativas e trajetórias tecnológicas: O caso da região oeste catarinense. Redes 2014, 19, 113-129. (In Portuguese) [CrossRef]

10. Casieri, A.; Nazzaro, C.; Roselli, L. Trust building and social capital as development policy tools in rural areas. An empirical analysis: The case of the LAG CDNISAT. New Medit. 2010, 9, 24-30. 
11. Casieri, A.; De Gennaro, B.; Medicamento, U. Framework of economic institutions and governance of relationships inside a territorial supply chain: The case of organic olive oil in the sierra de segura (Andalusia). Cah. Agric. 2008, 17, 537-541.

12. Arl, V. Caderno de Formação 01; Rede Ecovida de Agroecologia: Lapa, Brazil, 2007.

13. Arns, C.E.; Zuniga, G.; Rover, O.J. Relatório Sobre um Projeto de Desenvolvimento Sustentável e Alternativo para a Região Sul do Brasil com Base em Reflexões e Práticas de Organizações do Campo Popular; Coordenação dos Fóruns da Região Sul do Brasil: Curitiba, Brazil, 2002.

14. ECOVIDA ONLINE. Available online: http://www.ecovida.org.br (accessed on 18 November 2015).

15. Darolt, M.; Grando, G.; Almeida, F. Cartilha: Circuito Sul de Circulação e Comercialização de Alimentos Ecológicos; Rede Ecovida de Agroecologia: Curitiba, Brazil, 2016.

16. ECOVIDA ONLINE. Available online: http://www.ecovida.org.br/?sc=SA002\&stp=STP0002 (accessed on 18 February 2011).

17. Frison, E.; Rover, O.J. Entraves para a certificação orgânica do leite numa central cooperativa de agricultores familiares do oeste catarinense. Revista Brasileira de Agroecologia 2014, 9, 70-83. (In Portuguese)

18. Lamine, C.; Darolt, M.; Brandenburg, A. The Civic and Social Dimensions of Food Production and Distribution in Alternative Food Networks in France and Southern Brazil. Int. J. Sociol. Agric. Food 2012, 19, 383-401.

19. Magnanti, N.J. Circuito Sul de Circulação de Alimentos da Rede Ecovida de Agroecologia. Agriculturas 2008, 5, 26-29. (In Portuguese)

20. Meirelles, L. A Rede Ecovida de Agroecologia hoje. In Proceedings of Palestra Proferida Durante o VII Encontro Ampliado da Rede Ecovida de Agroecologia, Ipê, Brasil, 13-15 November 2009.

21. Meirelles, L. A Rede Ecovida de Agroecologia. Carta Maior. Maio de 2016. Available online: http:// cartamaior.com.br/?/Editoria/Meio-Ambiente/A-Rede-Ecovida-de-Agroecologia/3/36143 (accessed on 27 September 2016).

22. Perez-Cassarino, J. A Construcao Social de Mecanismos Alternativos de Mercados no Ambito da Rede Ecovida de Agroecologia. Ph.D. Thesis, Universidade Federal do Paraná, Curitiba, Brazil, 2012.

23. Rover, O.J. Agroecologia, mercado e inovação social: O caso da Rede Ecovida de Agroecologia. Ciências Sociais Unisinos 2011, 47, 56-63. (In Portuguese) [CrossRef]

24. Rover, O.J.; LAMPA, F.M. Rede Ecovida de Agroecologia: Articulando trocas mercantis com mecanismos de reciprocidade. Revista Agriculturas 2013, 10, 22-25.

25. Willer, H.; Lenoud, J. The World of Organic Agriculture: Statistics and Emerging Trends 2014; Research Institute of Organic Agriculture (FiBL): Frick, Switzerland; IFOAM-Organics International: Bonn, Germany, 2014.

26. Villasante, T.R. Redes e Alternativas: Estratégias e Estilos Criativos na Complexidade Social; Vozes: Petrópolis, Brazil, 2002.

27. Renting, H.; Marsden, T.K.; Banks, J. Understanding alternative food networks: Exploring the role of short food supply chains in rural development. Environ. Plan. A 2003, 35, 393-411. [CrossRef]

28. Aguglia, L. La filiera corta: Una opportunità per agricoltori e consumatori. Agriregionieuropa 2009, 17, 16-20. (In Italian)

29. Sacchi, G.; Caputo, V.; Nayga, R.M. Alternative labeling programs and purchasing behavior toward organic foods: The case of the participatory guarantee systems in Brazil. Sustainability 2015, 7, 7397-7416. [CrossRef]

30. Ministério da Agricultura, Pecuária e Abastecimento-MAPA, Cadastro Nacional de Produtores Orgânicos. Available online: http:/ / www.agricultura.gov.br (accessed on 19 July 2016).

31. Instituto Brasileiro de Geografia e Estatística (IBGE). Censo Agropecuário. Available online: http:/ / www. ibge.gov.br/ (accessed on 27 September 2016).

32. Zaoual, H. Nova Economia das Iniciativas Locais: Uma Introdução ao Pensamento Pós-Global; Coppe/UFRJInstituto Alberto Luiz Coimbra de Pós-Graduação e Pesquisa de Engenharia: Rio de Janeiro, Brazil, 2006.

33. Pascucci, S. Governance structure, perception, and innovation in credence food transactions: The role of food community networks. Int. J. Food Syst. Dyn. 2010, 1, 224-236.

34. Renting, H.; Schermer, M.; Rossi, A. Building food democracy: Exploring civic food networks and newly emerging forms of food citizenship. Int. J. Sociol. Agric. Food 2012, 19, $289-307$.

35. Altieri, M.A.; Nicholls, C.I. Agroecology and the Search for a Truly Sustainable Agriculture. Available online: http:/ / www.agroeco.org/doc/agroecology-engl-PNUMA.pdf (accessed on 27 September 2016). 
36. Appadurai, A. Introduction: Commodities and the politics of value. In The Social Life of Things: Commodities in Cultural Perspective; Cambridge University Press: New York, NY, USA, 1988; pp. 3-63.

37. Food and Agriculture Organization of the United Nations (FAO). The State of Food and Agriculture: Innovation in Family Farming; FAO: Rome, Italy, 2014.

(c) 2016 by the authors; licensee MDPI, Basel, Switzerland. This article is an open access article distributed under the terms and conditions of the Creative Commons Attribution (CC-BY) license (http:/ / creativecommons.org/licenses/by/4.0/). 